\title{
Characterization of Size and Density Separated Fractions of a Bituminous Coal as a Feedstock for Entrained Slagging Gasification
}

\author{
Nari Soundarrajan ${ }^{1}$, Nandakumar Krishnamurthy ${ }^{1}$, Sarma V. Pisupati ${ }^{1,2}$ \\ ${ }^{1}$ John and Willie Leonie Family Department of Energy and Mineral Engineering and EMS Energy Institute, The Pennsylvania State \\ University, University Park, USA \\ ${ }^{2}$ National Energy Technology Laboratory, US Department of Energy, Morgantown, USA \\ Email: sxp17@psu.edu
}

Received August 22, 2013; revised September 23, 2013; accepted September 30, 2013

Copyright (C) 2013 Nari Soundarrajan et al. This is an open access article distributed under the Creative Commons Attribution License, which permits unrestricted use, distribution, and reproduction in any medium, provided the original work is properly cited.

\begin{abstract}
Coal is one of the main sources of energy in many parts of the world and has one of the largest reserves/production ratios amongst all the non-renewable energy sources. Gasification of coal is one among the advanced technologies that has potential to be used in a carbon constrained economy. However, gasification availability at several commercial demonstrations had run into problems associated with fouling of syngas coolers due to unpredictable flyash formation and unburnt carbon losses. Computer models of gasifiers are emerging as a powerful tool to predict gasifier performance and reliability, without expensive testing. Most computer models used to simulate gasifiers tend to model coal as a homogenous entity based on bulk properties. However, coal is a heterogeneous material and comminution during feedstock preparation produces particle classes with different physical and chemical properties. It is crucial to characterize the heterogeneity of the feedstocks used by entrained flow gasifiers. To this end, a low ash US bituminous coal that could be used as a gasifier feedstock was segregated into density and size fractions to represent the major mineral matter distributions in the coal. Float and sink method and sieving were employed to partition the ground coal. The organic and inorganic content of all density fractions was characterized for particle size distribution, heating value, ultimate analysis, proximate analysis, mineral matter composition, ash composition, and petrographic components, while size fractions were characterized for heating value, ash composition, ultimate and proximate analysis. The proximate, ultimate and high heating value analysis showed that variation in these values is limited across the range of size fractions, while the heterogeneity is significant over the range of density fractions. With respect to inorganics, the mineral matter in the heavy density fractions contribute significantly to the ash yield in the coal while contributing very little to its heating value. The ash yield across the size fractions exhibits a bimodal distribution. The heterogeneity is also significant with respect to the base-to-acid ratio across the size and density fractions. The results indicate that the variations in organic and inorganic content over a range of density and size classes are significant, even in the low ash, vitrinite rich coal sample characterized here. Incorporating this information appropriately into particle population models used in gasifier simulations will significantly enhance their accuracy of performance predictions.
\end{abstract}

Keywords: Slag; Fly-Ash; Entrained-Flow Gasifier; Clean Coal Technology; Mineral Transformations; Partioning

\section{Introduction}

Coal is an abundant and economical fuel source. It is used for supplying over $40 \%$ of the electricity in the United States and occupies a similar share at the global level too [1]. Global coal consumption rose by $5.4 \%$ in 2011 and retains the fastest growth among non-renewable fuels [2]. However, growing environmental concerns bring about an increased interest in the develop- ment of clean coal technologies, in particular, coal gasification [3,4]. The development of advanced technologies such as gasification and construction of new plants requires fundamental understanding of coal properties and their impact on gasifier performance [5-8].

Coal is a highly complex mineral in nature, due to the variations in vegetation origin and subsequent bio and geo chemical transformations, because of which the content and constitution of organic and inorganic matter in 
individual coal particles vary substantially [9]. Mineral matter associated with coal can exist as included, i.e. within the coal particle or extraneous. This heterogeneity difference in maceral types and mineral matter with varying physical and chemical nature leads to large variations in burning times of char particles during combustion and gasification [10-13]. Previous studies have shown that the coal particles having different maceral concentrates generate char particles of different structures [11-14]. As a result, pyrolysis-chars generated from different maceral concentrates show different burning times in combustion conditions: vitrinite rich coal particles exhibit short burning times while highly reflecting inertinite rich coal particles exhibit long burning times $[11,13]$.

Mineral matter in coal influences all aspects of coal utilization $[15,16]$. With an increase in mineral matter content and increase in grain sizes, a higher level of heterogeneity can be expected in coal particles [17]. Yu (in 2007) and Saikia (in 2011) have studied mineral matter in Chinese and Indian coals respectively and found that included minerals are in general finer than excluded mineral matter $[18,19]$. Slater and coworkers conducted a focused study on pyrite and illite associations in two US bituminous coals [20]. They found that pyrite tends to occur commonly as excluded and non-associated while illite is more often found as an included form within the coal organic matrix or/and associated with other minerals. Mineral matter influences the burning times, abrasion of coal handling units, slagging in fireside surfaces of furnace, fouling in the heat recovery section and also affects in many other ways like corrosion, particulate emissions etc., [15,21-23].

Even in vitrinite rich coals with high caking tendency, coal particles with substantial mineral matter loading show a different burning profile than particles without mineral loading [24,25]. The mineral matter content, properties like particle sizes, fixed carbon, volatiles, and $\mathrm{HHV}$, also influence the unburnt carbon in char [26,27].

Hence, the study of variations in physical and chemical characteristics of coal particles over a range of density and size fractions of coal particles would be useful in developing a model to predict char kinetics during combustion and gasification. From that point of view, the variations in HHV, volatiles, petrology, ash yield, and mineral matter composition, ash yield composition over a wide range of particles sizes and density cuts have been assessed.

\section{Experimental Methods: Preparation and Characterization of Samples}

A barrel ( $\sim 900 \mathrm{~kg})$ of bituminous coal (Pittsburgh No. 8) was ground in an industrial rod mill and a sample of particle size distribution similar to that used in a commercial pressurized entrained flow slagging gasifier was obtained. A representative sample of the ground coal was separated by float-sink experiments into four density fractions by utilizing separation liquids of various precise densities (reported at $\left.20^{\circ} \mathrm{C}\right)$. Mixtures of toluene $(0.87 \mathrm{~g} / \mathrm{cc}$ at), perchloroethylene $(1.62 \mathrm{~g} / \mathrm{cc})$ and $1,1,2,2$ tetrabromoethane $(2.96 \mathrm{~g} / \mathrm{cc})$ were used to formulate the separation media at $1.3 \mathrm{~g} / \mathrm{cc}, 1.6 \mathrm{~g} / \mathrm{cc}$ and $2.6 \mathrm{~g} / \mathrm{cc}$. The whole coal sample is identified as SG0PS0 and the four density fractions in are identified as SG1 $(<1.3 \mathrm{~g} / \mathrm{cc}), \mathrm{SG} 2(1.3$ to $1.6 \mathrm{~g} / \mathrm{cc}$ ), SG3 (1.6 to $2.6 \mathrm{~g} / \mathrm{cc}$ ) and SG4 (>2.6 g/cc). Each density fraction was sieved further into seven size classes. A representative sample of the whole coal sample (SG0PS0) was also separated into the same seven size fractions. The size segregations in decreasing order of particle size are identified as PS1, PS2, PS3, PS4, PS5, PS6 and PS7. The methodology followed in segregating the sample and the size ranges are illustrated in Figure 1.

The yields of ash and volatiles for the size and density fractions were determined using a LECO proximate analyzer. Ultimate analyses on the size and density fractions were performed using a LECO CHN and Sulfur analyzers and an Anton-Parr bomb calorimeter. The mineral matter content was estimated using the Parr correction formula [15]. The oxides of such high temperature ashes were evaluated by Inductively Coupled Plasma Atomic Emission Spectrometry (ICP-AES) techniques on a Perkin Elmer apparatus. Petrographic evaluation of the density fractions was conducted by preparing samples according to ASTM D2797. Macerals in whole coal were identified in accordance with ASTM D2799 using a Zeiss Universal Research microscope at $625 \times$ magnification with polarized white-light illumination.

Mineral matter in the coal was identified and estimated by more than one method. Samples were prepared and shipped to an external laboratory at the University of North Dakota for Computer Controlled Scanning Electron Microscopy (CCSEM) [28]. CCSEM yielded quailtative mineral data as well as quantitative data for the whole coal (BSG0PS0) and two of the heavier fractions (BSG3PS0, BSG4PS0). Mineral matter was also identified by means of X-ray diffraction (XRD) of finely powdered samples taken from each particle class. However the XRD method was restricted to identification of minerals that were present in the crystalline form. Iron minerals in the coal samples (BSG0PS0, BSG3PS0 and BSG4PS0 samples) were determined by Mossbauer spectroscopy conducted on the samples at University of Kentucky [29].

\section{Results and Discussions: Heterogeneity of Density and Size Fractions}

Although the variations in characteristics are expected 
over a range of size and density fractions in comparison with whole coal, quantification of such variation is more desirable. This section focuses on various physical and chemical variations of the segregated fractions.

\subsection{Yields on Gravity Partitioning}

The gravity distribution of the coal, as tabulated in the first row of Table 1, shows that most of the coal (95.4 wt. $\%$ ) floats in a liquid of 1.6 specific gravity. The contribution of lighter gravity fractions SG1 and SG2 are nearly even with respect to yield, at $47.8 \%$ and $47.6 \%$ by weight, respectively. Only a small quantity $(3.49 \%$ in the 1.6 2.6 specific gravity and $1.10 \%$ in the 2.6 sink) is present in the heavier fractions. The distribution is expected as the average specific gravity of bituminous coal to be $\sim 1.4$.

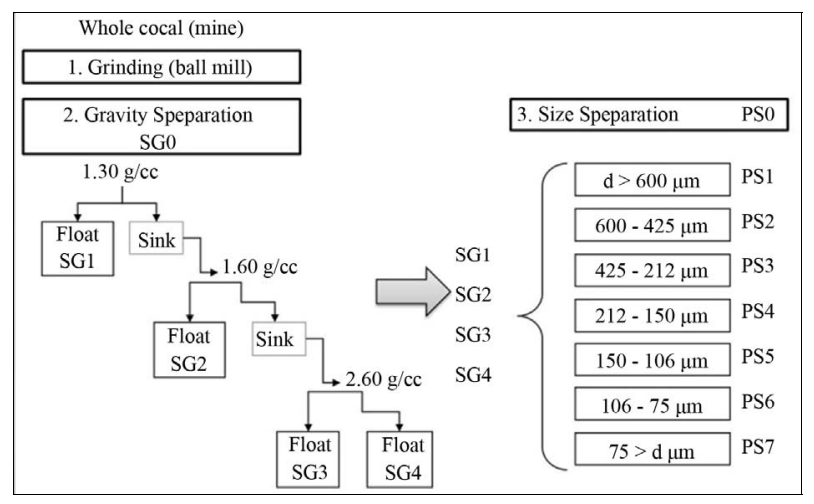

Figure 1. Density and size separated sample preparation flow diagram. SG0 is the whole coal; PSO indicates that the sample has not been separated by size after density separation; "specific gravity" is used interchangeably with density in the text.

Table 1. Proximate, ultimate and HHV analysis of whole coal and various density fractions.

\begin{tabular}{cccccc}
\hline & SG0 & SG1 & SG2 & SG3 & SG4 \\
\hline Yield, wt \% & 100 & 47.8 & 47.6 & 3.5 & 1.1 \\
Moisture, wt \% & 2.08 & 2.1 & 2.2 & 2.0 & 0.6 \\
Ash, wt \% & 8.9 & 2.6 & 10.71 & 51.6 & 65.4 \\
Volatile Matter, wt \% & 36.2 & 39.5 & 34.4 & 21.1 & 19.2 \\
Fixed Carbon, wt \% & 52.9 & 55.8 & 52.8 & 25.4 & 14.9 \\
Heating value, MJ/kg & 33.8 & 36.3 & 32.9 & 12.9 & 7.3 \\
Ultimate analysis (dry basis) & & & \\
C & 77.9 & 84.7 & 76.2 & 30.9 & 6.4 \\
H & 5.6 & 6.0 & 5.4 & 2.1 & 0.3 \\
N & 1.4 & 1.5 & 1.4 & 0.5 & 0.2 \\
S & 1.9 & 1.0 & 1.6 & 8.5 & 36.0 \\
O (by diff) & 4.4 & 4.1 & 4.6 & 6.5 & 0.0 \\
\hline
\end{tabular}

\subsection{Particle Size Distribution (PSD) Analysis}

The particle size distribution (PSD) of each density fraction, as determined by sieve analysis, was compared with utility grinds and a commercially used PSD curve shared by a gasification vendor. The particle size distribution of each density fraction was found to be following RosinRammler distribution [30]. Figure 2 presents a compareson of the log-log particle size distributions of the whole coal (SG0PS0) with that of the four gravity fractions, a commercial gasifier grind (curve A) and a utility (pf combustion) grind. The PSD of SG2 and SG4 cluster but they are away from that of SG1 and SG3. A notable point is the wide disparity between the utility grind (which follows a Rosin-Rammler type distribution) and the gasifier grinds, which may be because curve A was much coarser. The mean particle size (MPS), which is simply the weight averaged particle size of a fraction, of whole coal and density fractions are: Bulk coal at $260 \mu \mathrm{m}$, SG1 at $287 \mu \mathrm{m}, \mathrm{SG} 2$ at $222 \mu \mathrm{m}, \mathrm{SG} 3$ at $414 \mu \mathrm{m}$ and SG4 at $264 \mu \mathrm{m}$ respectively. The variation in the mean particle size of the gravity fractions is an interesting phenomenon that needs to be investigated.

\subsection{Petrographic Analysis of Various Density Fractions}

Petrological composition is one of the important parameters that influence coal combustion and conversion [9]. The maceral composition of the whole coal and those of the four density fractions are presented in Figure 3. The maceral values for all the gravity fractions have been obtained by direct counting through an optical microscope. The values for fraction SG4 were obtained with considerable difficulty using a 360 point count (much lower than the normal 1000 point count) procedure. So the accuracy of extrapolating the maceral values for SG4 could be less than the other fractions. Considering the low yield of $1.12 \mathrm{wt} \%$ of that fraction the impact is far less significant [31]. The major maceral group found in the Eastern US bituminous coals is vitrinite and current results show good agreement [32]. The overall contribution of vitrinites from SG1 fraction clearly outweighs that from the other density fractions. The concentration of vitrinites is relatively low in SG3 fraction compared to other density fractions.

The other important maceral group is inertinites which is known to contribute significantly to unburnt carbon [33]. Fusinite, macrinite, micrinite, inertodendrite and semifusinites were grouped together as inertinites in this work. These higher density macerals, inertinites, are expected to be more concentrated in SG2 and SG3 fractions. Although the petrographic analyses indicate significant concentration of inertinites in SG3 fraction, the contribution of SG3 towards total inertinite is low due to lower SG3 yield. Like other macerals, the absolute contribution 


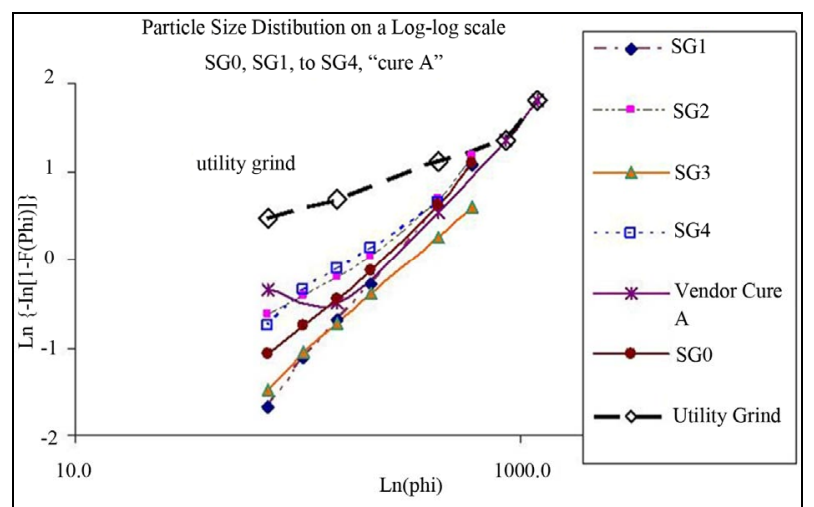

Figure 2. Comparison of the PSD of all fractions with a commercial gasification grind and a utility grind $(\mu \mathrm{m})$.

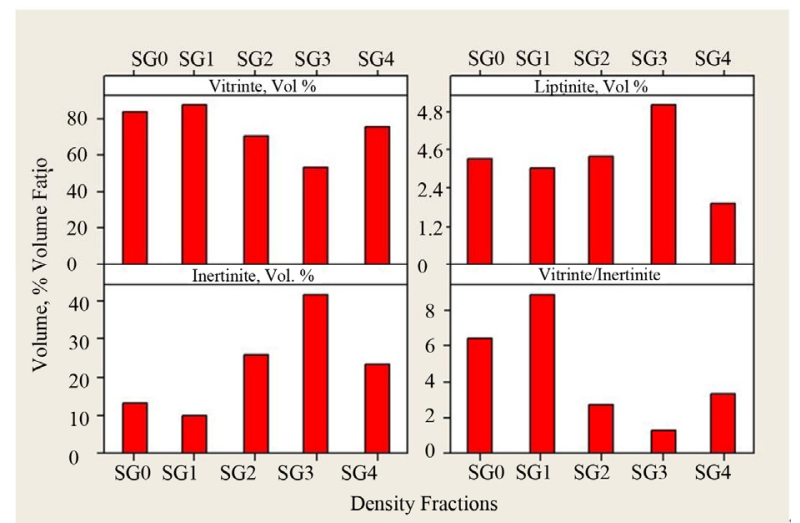

Figure 3. Distribution of macerals (mineral matter free basis) in various density fractions.

to inertinites from SG1 and SG2 fractions are significant due to higher yield of these fractions. However, a clear distinction is seen in total inertinites in SG2 (26.1\%) and SG1 (9.8\%) fraction.

The distinct comparisons between SG2 vs. SG1 are as follows: Fusinite $5.5 \%$ vs. $1.7 \%$, Semifusinite $11.4 \%$ vs. $5 \%$, Macrinite $0.4 \%$ vs. $0.3 \%$, Micrinite $3.1 \%$ vs. $1.8 \%$, and Inertodendrite $5.7 \%$ vs. $1.0 \%$. The segregation of inertinites in SG2 fraction is result of density of inertinites falling in the range of $1.3-1.6 \mathrm{~g} / \mathrm{cc}$.

The segregation of macerals in gravity fractions could be primarily due to the degree of their association with minerals and the fracture characteristics of both minerals and macerals. Following are the important observations on segregation and heterogeneity found in the different gravity fractions:

- Liptinite macerals, originating from res-ins/exines, are found relatively more in the SG3 fraction at $\sim 5 \%$, i.e., roughly $50 \%$ more than in SG1 and SG2. The higher concentration of liptinites in SG3 can be attributed to their bondage with minerals and conesquent lower grindability.

- In literature, segregation of macerals based on increasing density is reported to follow the order viz. inertinites $>$ vitrinites $>$ liptinites. Multimaceral lithotypes are also reported to be more in higher density fractions [24].

The other important observation is the reduced concentration of liptinites in the SG4 fraction despite having similar particle size distribution and mean particle size as SG2. This may be due to the limited organic content in the SG4 fraction. This study did not involve maceral analysis of the range of size fractions due to poor accuracy of counting with decrease in particle size and due to difficulty in demineralization of some size fractions.

\subsection{Proximate, Ultimate and HHV Analysis}

\subsubsection{Variations in Density Fractions}

Data from the proximate analysis of the four density samples is presented in Table $\mathbf{1}$ and shows the large variations in contribution to commercial value by each density fraction. As expected, the heavier fractions contain substantial mineral matter (or high ash yield), with consequent decrease in organic content and decline in heating value. The contribution of SG3 and SG4 fractions towards total heating value is very minimal. Heavier fractions are likely to be composed mostly of excluded minerals. To further confirm this reasoning, sulfur was analyzed (total sulfur) in all samples. The hypothesis was that the sulfur in SG3 and SG4 fractions should be much more than in other density fractions, if they have significant excluded Pyrites. The reasons behind the hypothesis are:

- Organic contribution in both the gravity fractions are low and therefore organic sulfur and included Pyrites are expected to be less.

- Earlier studies have shown that organic sulfur concentration is usually more in vitrinites, and vitrinite macerals are more abundant in low density fractions [34].

As expected, the concentration of Sulfur was found to increase with density. It is important to note that the sulfur reported here is total sulfur and not inorganic sulfur. The other constituents such as carbon, hydrogen and nitrogen naturally drop with density due to decreasing organic content. The HHV data of each density fractions gain importance in terms of critical values for deciding economic benefication. The contribution of SG3 and SG4 fractions to total HHV of coal is only $1.6 \%$. Therefore, it can said with confidence that SG3 and SG4 fractions could cause more harm through abrasion of coal handling plants than any calorific benefit provided [15]. However, if they play a crucial role in slag layer development, then these fractions could be justified in an entrained flow slagging gasifier.

\subsubsection{Variations in Size Fractions}

The other important aspect is to understand the variations 
within size fractions, as the particle size distribution fed to the pulverized coal fired boiler is usually of a wide range [35]. A similar analysis as carried out for gravity fractions were carried out for size fractions too. The results are presented in Table 2. Unlike density fractions, the yields in case of different size fractions are bimodal, with PS3 and PS7 together contributing to $55 \%$ of the total. No distinction could be drawn in terms of ash yield, volatile matter, HHV, fixed carbon content, and elemental composition. The results indicate that beneficiation of coal by the process of separating on the basis of size may not yield good results like density separation.

In summary, the proximate, ultimate, and HHV analysis show sharp distinctions with respect to different density fractions, while no significant variation is seen over the various size fractions.

\subsection{Heterogeneity of Mineral Matter}

Minerals in the whole coal are distributed as follows: iron minerals (pyrites, pyrrhotites and trace oxides): $37 \%$, aluminosilicates: 33\%, aluminosilicates with impurities: $16 \%$, pure quartz: $\sim 7 \%$, impure quartz: $3 \%$ with carbonates and sulfates accounting for the rest. During combustion or gasification, the included minerals undergo transformations differently compared to excluded minerals. For instance, in a combustion conditions, the included pyrites transform slowly to iron oxides, while the excluded pyrites transform relatively fast [36-39].

Evaluating the association of mineral matter viz. included vs. excluded, helps to ascertain the abrasion and slagging propensity on coal milling and handling systems. Therefore, computer controlled scanning electron microscope-automated image analysis (CCSEM) was used to analyze gravity fractions SG3, SG4 and whole coal sam- ple [28]. This method is used to determine the amount and nature of the mineral matter (excluded vs. included) in the coal samples. However, one of the limitations of CCSEM is that it can analyze particles between sizes $1 \mu \mathrm{m}$ to 300 $\mu \mathrm{m}$. Due to this limitation, all the particle classes (i.e. large particles) could not be analyzed in the original state. However, in order to analyze the entire sample from each gravity fraction, the particles larger than $300 \mu \mathrm{m}$ were ground to pass through a mesh screen with $300 \mu \mathrm{m}$ openings. Because of this size limitation the behavior of large particles during transformation $[20,36]$ can't be accurately assessed by CCSEM. However, particle larger than $300 \mu \mathrm{m}$ do not represent a large portion of the coal, so this is not expected to have any significant effect on predictions.

\subsubsection{Included and Excluded Minerals}

The composition of each mineral group in excluded and included form is shown in Figure 4. The CCSEM analy-

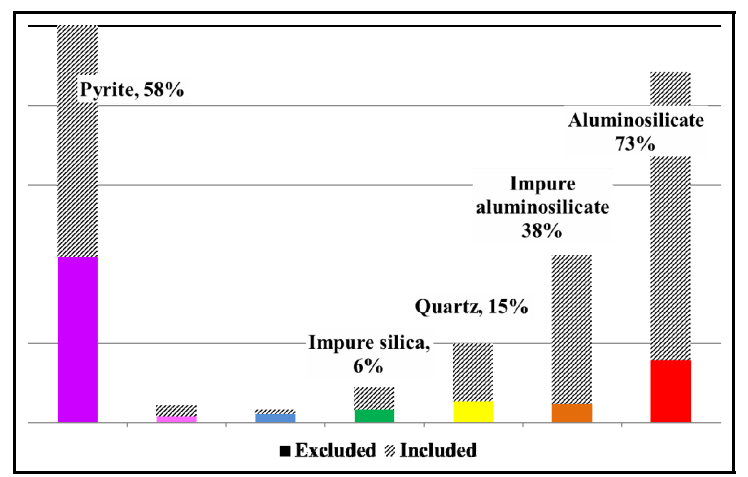

Figure 4. Relative proportion of the major minerals present in included form in the coal. Over half the pyrite and $3 / 4^{\text {th }}$ of the aluminosilicates are present as included minerals. Carbonates and sulfates are in trace amounts.

Table 2. Proximate, ultimate and HHV analysis of bulk and various size fractions.

\begin{tabular}{|c|c|c|c|c|c|c|c|c|}
\hline PSD, $\mu \mathrm{m}$ & Bulk & $d>600$ & $600-425$ & $425-212$ & $212-150$ & $150-106$ & $106-75$ & $75>d$ \\
\hline & PSO & PS1 & PS2 & PS3 & PS4 & PS5 & PS6 & PS7 \\
\hline Yield, wt\% & & 5.1 & 10.2 & 26.2 & 11.2 & 9.5 & 8.9 & 28.9 \\
\hline Moisture, wt\% & 2.1 & 2.4 & 2.0 & 1.9 & 1.9 & 1.9 & 1.9 & 1.8 \\
\hline Volatile matter, wt\% & 36.2 & 35.1 & 36.3 & 36.8 & 37.5 & 36.5 & 36.3 & 36.5 \\
\hline Ash, wt\% & 9.1 & 8.11 & 9.0 & 9.3 & 9.3 & 9.3 & 9.9 & 10.6 \\
\hline Fixed carbon, wt \% & 52.7 & 54.4 & 52.7 & 52.1 & 51.4 & 52.2 & 51.9 & 51.1 \\
\hline HHV, MJ/kg & 33.8 & 33.5 & 33.7 & 33.8 & 33.8 & 34.0 & 33.9 & 33.8 \\
\hline \multicolumn{9}{|c|}{ Ultimate analysis (dry basis) } \\
\hline Carbon, wt\% & 76.3 & 76.8 & 77.3 & 77.7 & 77.9 & 78.3 & 76.3 & 76.3 \\
\hline Hydrogen, wt \% & 5.6 & 5.5 & 5.6 & 5.6 & 5.5 & 5.6 & 5.6 & 5.6 \\
\hline Sulfur, wt \% & 2.0 & 2.0 & 2.1 & 2.1 & 2.2 & 2.1 & 2.0 & 2.0 \\
\hline Oxygen $^{*}$, wt \% & 4.1 & 4.3 & 4.3 & 3.9 & 3.8 & 3.7 & 4.7 & 4.1 \\
\hline
\end{tabular}

*Oxygen calculated by difference. 
ses of whole coal (SG0 indicates that over $72 \%$ of mineral matter occurs as included minerals. Nearly $58 \%$ of the pyrite present is found as included mineral, and about $73 \%$ aluminosilicates and $15 \%$ quartz are present in the included form. Over $80 \%$ of the pyrite in SG3 fraction and nearly $90 \%$ of the pyrite in the SG4 fraction is present in the excluded form. Juxtaposing this data with other observations (of ash yield and sulfur analysis) seems to indicate that bulk of the included pyrite may be contained in the SG2 fraction. Bulk of the included aluminosilicates are however present in the SG3 fraction. Minerals with impurities show lower melting points and are grouped separately.

\subsubsection{Segregation of Minerals in Density Fractions}

The SG3 and SG4 fractions together contribute 28.5\% towards total ash yield of coal, while SG2 fraction alone contributes $\sim 57 \%$ towards total ash yield. Therefore, it can be suggested that the SG2 fraction has significant included mineral matter and naturally the mineral matter in SG1 fraction is also dominated by included minerals. Figure 4 also shows that aluminosilicates and pyrites dominate the included minerals.

The proportional variations of each mineral constituent viz. aluminosilicates, pyrites and quartz, with respect to different size cuts for whole coal and density fractions SG4, SG3 and SG1 + SG2 (a composite representation) are shown in Figure 5. The minerals present in SG1 + SG2 fractions were calculated based on CCSEM data of whole coal, SG3 and SG4 fractions. The contribution of mineral matter from SG1 + SG2 fraction is predominant. The contribution from SG3 and SG4 fractions towards total mineral matter is relatively lesser.

\subsubsection{Comparative Study of Minerals by XRD and Mossbauer Spectroscopy Techniques}

To further confirm the presence of above said minerals and determine iron compounds in SG3 and SG4 fractions, Table 3 Mossbauer spectroscopy was carried out (at University of Kentucky) on those two fractions. X-ray diffraction analysis was also carried out on all the fractions to identify the minerals present in the coal samples. XRD of raw coals was a slightly challenging process because of background noise due to the amorphous carbon present in coal. By overlaying XRD pattern obtained for pure mineral samples on a coal-mineral mixture pattern, the background and extraneous peaks from amorphous materials can be identified and removed by trained operators. The remaining curve with the mineral peaks is used to identify the crystalline matter [40-42]. Table 4
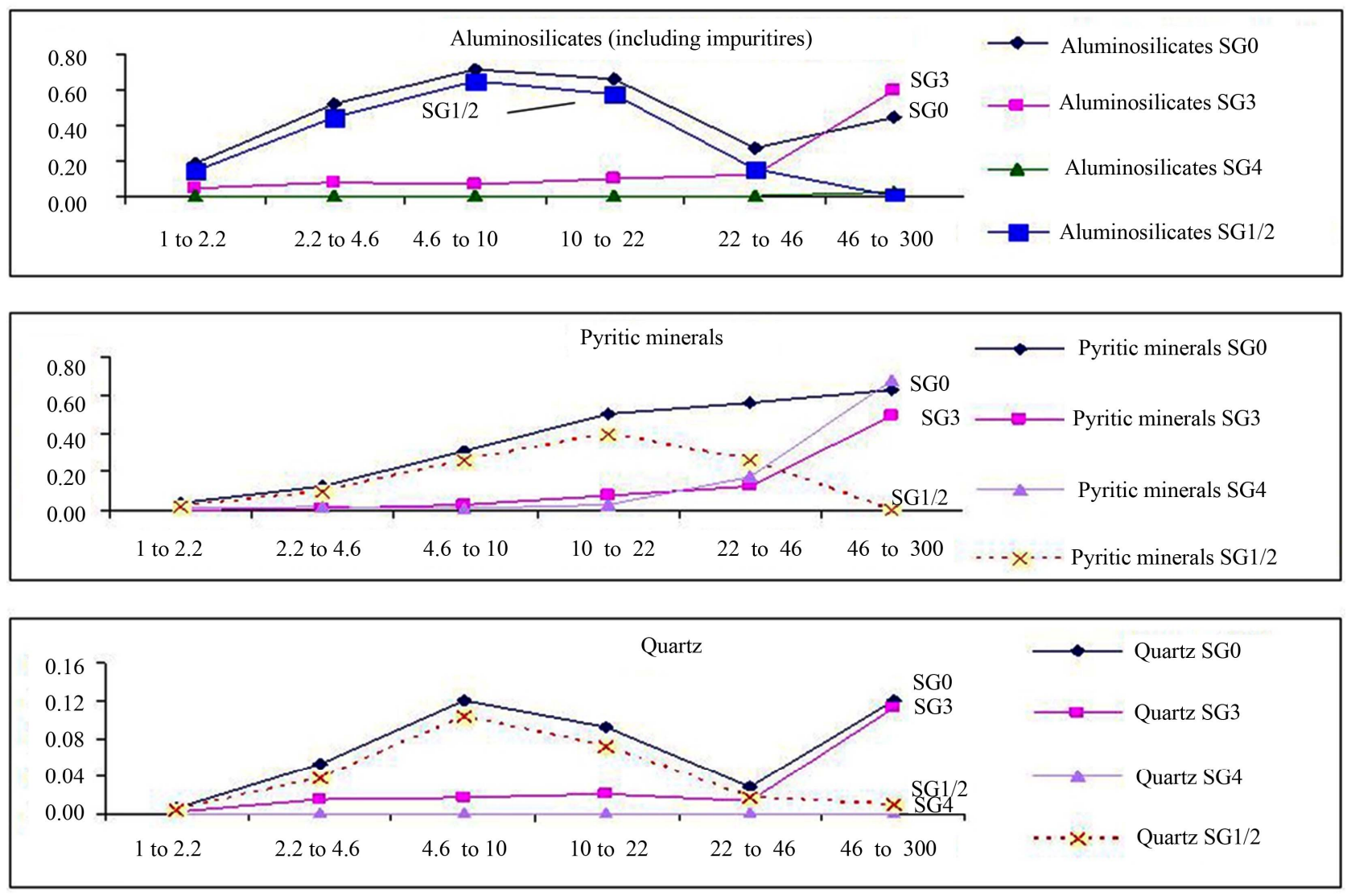

Figure 5. Size variation of key minerals across density fractions (X-axis in $\mu \mathrm{m})$. The $\mathrm{Y}$-axis is an arbitrary scale. 
Table 2. Distribution of key minerals by particle/mineral size and comparisons between SG3 and SG4 minerals.

\begin{tabular}{cl}
\hline Density Fractions & Trend of Mineral Particle Sizes \\
\hline SG1 + SG2 & $\begin{array}{l}\text { The contents of aluminosilicates and quartz in different size fractions almost follows the } \\
\text { trend of whole coal and the mode occurs in the } 4.6 \text { to } 10 \mu \mathrm{m} \text { size rang } \\
\text { The pyrite particles are more than in SG3 and SG4 up to } 46 \mu \mathrm{m} \text { but reduces in bigger size particles }\end{array}$ \\
& $\begin{array}{l}\text { Aluminosilicates and Quartz are in very small quantity but higher than in the SG4 fraction in all sizes upto } 46 \mu \mathrm{m} \text { but in- } \\
\text { creases rapidly above that up to } 460 \mu \mathrm{m} \\
\text { Pyrites are present in small quantity but higher than in SG4 fraction in all sizes up to } 46 \mu \mathrm{m} \text { but increases rapidly above that } \\
\text { up to } 460 \text { microns }\end{array}$ \\
& $\begin{array}{l}\text { Aluminosilicates and quartz are very negligible in all sizes. } \\
\text { Pyrite also is negligible up to } 22 \mu \mathrm{m} \text { size and increases significantly above } 46 \mu \mathrm{m}\end{array}$ \\
\hline
\end{tabular}

Table 3. Minerals identified in heavy density fractions using multiples techniques.

\begin{tabular}{|c|c|c|c|}
\hline Samples/ Techniques & XRD & CCSEM & Mossbauer \\
\hline SG4 (density > $2.6 \mathrm{~g} / \mathrm{cc}$ ) & $\begin{array}{l}\text { Pyrite, Marcasite, Magnetite, } \\
\text { Calcite, Kaolinite (trace), } \\
\text { Potassium Silicate. }\end{array}$ & $\begin{array}{l}\text { Pyrite, Pyrrhotite, oxidized Pyrite, iron-rich } \\
\text { compounds, Si and Al rich matter. }\end{array}$ & $\begin{array}{l}\text { Szomolnokite, Pyrite, } \\
\text { Jarosite, magnetite. }\end{array}$ \\
\hline SG3 (density = $1.6-2.6 \mathrm{~g} / \mathrm{cc})$ & $\begin{array}{c}\text { Pyrite, Marcasite, Quartz, Calcite, } \\
\text { Kaolinite, Illite, } \\
\text { Sodium-aluminosilicate, Jarosite. }\end{array}$ & $\begin{array}{l}\text { Pyrite, Pyrrhotite, Quartz, Calcite, Ankerite, } \\
\text { Kaolinite, Gypsum, mixed Aluminosilicates, } \\
\text { Illite-montmorillonite, and Si/Ca-rich matter. }\end{array}$ & $\begin{array}{c}\text { Jarosite, } \mathrm{Fe}^{2+} \text { in clay and } \\
\text { Pyrite. }\end{array}$ \\
\hline
\end{tabular}

lists the minerals identified by each technique. Salient observations from the comparative study are as below:

- The analysis showed that over $80 \%$ of the iron is present as iron sulfides.

- Some of the iron in the SG3 phase is present inside the clays in the $\mathrm{Fe}^{2+}$ oxidation state.

- Mossbauer analysis provided confirmation of the presence of Jarosite and Magnetite in the SG4 fractions, which was also identified by XRD.

- CCSEM methods were not accurate in quantifying any magnetite or jarosite in the samples but detected the presence of ankerite and gypsum in the coal.

- The key observation was that no single technique can completely and accurately identify all the minerals phases. However, depending on the proportion of the minerals, judicious choices can be made in the interest of time and cost.

- XRD stands out in terms of quick sample preparation, small quantity requirement and fairly rapid analysis, once the user becomes well versed with a suite of coal minerals.

\subsubsection{Trends of Mineral Contents in Different Size Partitions of Whole Coal}

The particle size information of various mineral constituents is important to understand abrasion, erosion, beneficiation, and vaporization of minerals in coal utility systems. Raask reported that certain mineral particles with high Mho's index contribute to abrasion only when the particle size is greater than $20 \mu \mathrm{m}$ and should exist as excluded minerals [15]. Liu et al., have reported that if mineral particles are lesser than $20 \mu \mathrm{m}$, the mineral re- moval ratio markedly decrease, the mineral removal showing no improvement even after pulverizing to 10 $\mu \mathrm{m}$ or less due to difficulties in separating mineral matter and organic matter $[43,44]$. Also, the mineral particles, especially included minerals, have propensity for vaporization and could form deposits in the lower temperature heat transfer zones [28]. However, the slagging propensity depends on the kind of minerals present in coal.

Figure 6 shows the variation in distribution over a range of particle sizes for major mineral (Table 3) constituents. The key minerals are pyrite, aluminosilicates and impure aluminosilicates. The figure shows that the significant portion of all mineral matter constituents have particle size less than $46 \mu \mathrm{m}$. This further confirms the substantial contribution of included mineral matter (usually present as finely divided minerals in the organic matrix).

\section{Summary and Conclusions}

Size and density separated fractions of Pittsburgh No.8 coal were analyzed for their variations in organic and inorganic content. Proximate, ultimate, HHV, CCSEM, XRD, Mossbauer spectroscopy and petrographic analysis were performed to deduce the variations of organic and inorganic content. Key findings are reported below:

- Based on the proximate, ultimate and HHV analysis, fractions having density of $1.6 \mathrm{~g} / \mathrm{cc}$ and above (SG3 and SG4) constitute only $4.59 \%$ of whole coal physically and having only $1.56 \%$ heat content, reduce the quality of the coal by contributing primarily mineral matter $(28.5 \%$ of whole ash) which are potential source of many problems. 


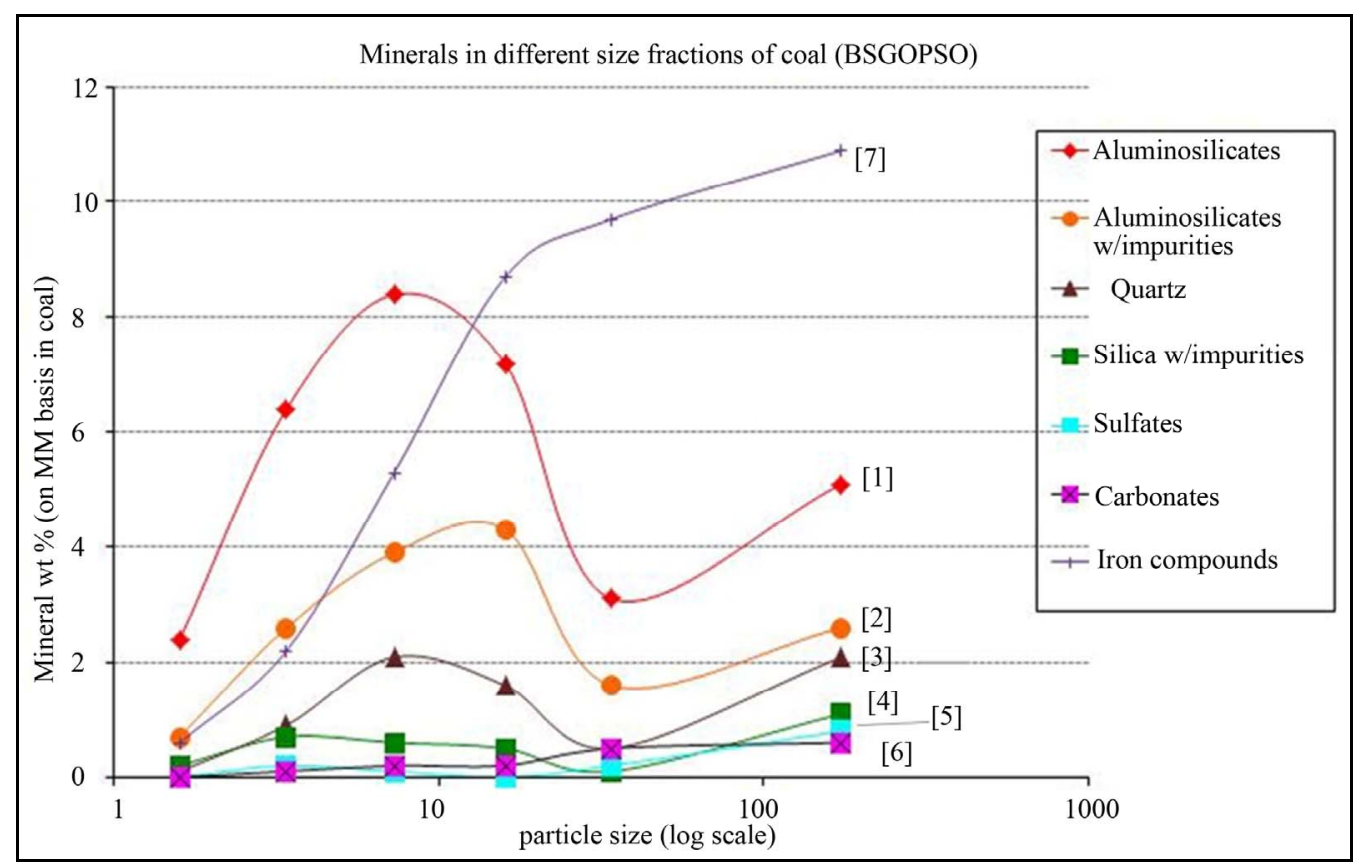

Figure 6. Segregation of minerals in different size fractions (X-axis in $\mu \mathrm{m})$. The numbering legend is to help distinguish the symbols and has no other significance.

- The present study reveals that the Particle Size Distribution (PSD) of the gravity fractions vary significantly. The mean particle size (MPS), which is simply the weight averaged particle size, of whole coal and density fractions are: Bulk coal at $260 \mu \mathrm{m}$, SG1 $(<$ 1.3 sp.gr $)$ at $287 \mu \mathrm{m}, \mathrm{SG} 2((1.3-1.6 \mathrm{sp} . \mathrm{gr})$ at $222 \mu \mathrm{m}$, SG3 (1.6 - 2.6 sp.gr) at $414 \mu \mathrm{m}$ and SG4 (>2.6 sp.gr) at $264 \mu \mathrm{m}$ respectively.

- The variation of organic and inorganic constituents across the density gradient is more obvious compared to variations across size gradient.

- CCSEM analyses of whole coal indicate that over $72 \%$ of mineral matter occurs as included minerals Pyrites and aluminosilicates with impurities constitute major contents of the included minerals. The contribution of excluded minerals is predominantly from the high density fractions, while the included minerals are seen in lower density fractions.

- The distribution of minerals across size fractions is heterogeneous. Pyrites are present in relatively larger proportions in the coarser fractions while aluminosilicates are distributed in a more bimodal manner.

Since many minerals are present in included form hot stage microscopic XRD studies of the different size fractions will be of great value to observe in-situ transformations. For the evaluation of minerals CCSEM, XRD and Mossbauer techniques were deployed. The key observation was that no single technique can completely and accurately identify all the minerals phases. XRD stands out in terms of quick sample preparation, small quantity requirement and fairly rapid analysis, once the user be- comes well versed with a suite of coal minerals. CCSEM methods were not accurate in quantifying any Magnetite or Jarosite in the samples but detected the presence of Ankerite and Gypsum in the coal. CCSEM is essential to assess the size distribution of minerals.

This study of partitioning a bituminous coal into four density fractions and further into seven particle size fractions (for each gravity fraction) has revealed that heterogeneity in the coal is very much multidimensional and needs to be a strong consideration in modeling coal particles in applications involving pulverized feedstocks. Apart from the variations in fixed carbon, volatiles and ash content across the fractions, there is a strong variation in the distribution of each mineral species, by content, chemical purity, the degree of co-existence with other minerals, particle size distribution of each mineral as well as their included/excluded nature. Further population model studies of typical US coals can lead to the establishment of the pattern(s) of heterogeneity of the organic matter and inorganic matter in US coals. These population models can aid in the improvement of computer models for gasification and better prediction of gasifier performance and reliability.

\section{Acknowledgements}

This technical work was performed in support of National Energy Technology Laboratory's (NETL) research in Slagging Gasifier Model Development under the RES contract 0004000 . Assistance of personnel and use of facilities at the EMS Energy Institute and Materials Re- 
search Laboratory (Penn State) is appreciated. Assistance in sample preparation by CONSOL Energy Inc. (Library PA) and METSO Minerals (York PA) is sincerely acknowledged.

\section{REFERENCES}

[1] Electricity in the United States, 2013. http://www.eia.gov/energyexplained/index.cfm?page=ele ctricity_in_the_united_states

[2] BP Statistical Review of World Energy, 2012. http://www.bpamoco.com/worldenergy

[3] S. Shelley, "Coal Gasification Comes of Age," Chemical Engineering Progress, Vol. 102, No. 6, 2006, pp. 6-10.

[4] L. Wang, Y. Yang, T. Morosuk and G. Tsatsaronis, "Advanced Thermodynamic Analysis and Evaluation of a Supercritical Power Plant," Energies, Vol. 5, No. 6, 2012, pp. 1850-1863. http://dx.doi.org/10.3390/en5061850

[5] R. Gupta, "Advanced Coal Characterization: A Review," Energy \& Fuels, Vol. 21, No. 2, 2007, pp. 451-460. http://dx.doi.org/10.1021/ef060411m

[6] M. Massoudi and P. Wang, "Slag Behavior in Gasifiers. Part II: Constitutive Modeling of Slag," Energies, Vol. 6, No. 2, 2013, pp. 807-838. http://dx.doi.org/10.3390/en6020807

[7] Tampa Electric Integrated Gasification Combined Cycle Project, Project Performance Summary, Tampa, 2004. http://www.netl.doe.gov/technologies/coalpower/cctc/cctdp /bibliography/demonstration/pdfs/tampa/Tampa_PPS.pdf

[8] Duke Energy's Edwardsport IGCC Powerplant Begins Commercial Operation, 2013. http://www.duke-energy.com/news/releases/2013061001.asp

[9] R. C. Neavel, "Origin, Petrography and Classification of Coal. Chemistry of Coal Utilization," In: M. A. Elliott, Ed., John Wiley and Sons, New York, 1981.

[10] K. E. Benfell, et al., "Modeling Char Combustion: The Influence of Parent Coal Petrography and Pyrolysis Pressure on the Structure and Intrinsic Reactivity of Its Char," Proceedings of the Combustion Institute, Vol. 28, 2000, pp. 2233-2241. http://dx.doi.org/10.1016/S0082-0784(00)80633-5

[11] T. F. Wall, et al., "The Temperature, Burning Rates and Char Character of Pulverised Coal Particles Prepared from Maceral Concentrates," Symposium (International) on Combustion, Vol. 24, No. 1, 1992, pp. 1207-1215.

[12] J. G. Bailey, A. Tate, C. F. K. Diessel and T. F. Wall, “A Char Morphology System with Applications to Coal Combustion", Fuel, Vol. 69, No. 2, 1990, pp. 225-239. http://dx.doi.org/10.1016/0016-2361(90)90179-T

[13] R. B. Jones, C. B. McCourt, C. Morley and K. King, "Maceral and Rank Influences on the Morphology of Coal Char," Fuel, Vol. 64, No. 10, 1985, pp. 1460-1467. http://dx.doi.org/10.1016/0016-2361(85)90351-5

[14] R. S. Winburn, D. G. Grier, G. J. McCarthy and R. B. Peterson, "Rietveld Quantitative X-Ray Diffraction Analysis of NIST Fly Ash Standard Reference Materials," Powder Diffraction, Vol. 15, No. 3, 2000, pp. 163-172.
http://dx.doi.org/10.1017/S0885715600011015

[15] E. Raask, "Mineral Impurities in Coal Combustion: Behavior, Problems, and Remedial Measures," Hemisphere Publishing Corporation, Washington, 1985, $484 \mathrm{p}$.

[16] C. R. Ward, "Analysis and Significance of Mineral Matter in Coal Seams," International Journal of Coal Geology, Vol. 50, No. 1-4, 2002, pp. 135-168. http://dx.doi.org/10.1016/S0166-5162(02)00117-9

[17] V. Manovic, D. Loncarevic and R. Tokalic, "Particleto-Particle Heterogeneous Nature of Coals: A Case of Large Coal Particles," Energy Sources Part A-Recovery Utilization and Environmental Effects, Vol. 31, No. 5, 2009, pp. 427-437.

[18] D. X. Yu, et al., "Computer-Controlled Scanning Electron Microscopy (CCSEM) Investigation on the Heterogeneous Nature of Mineral Matter in Six Typical Chinese Coals," Energy \& Fuels, Vol. 21, No. 2, 2007, pp. 468476. http://dx.doi.org/10.1021/ef060419w

[19] B. K. Saikia and Y. Ninomiya, "An Investigation on the Heterogeneous Nature of Mineral Matters in Assam (India) Coal by CCSEM Technique," Fuel Processing Technology, Vol. 92, No. 5, 2011, pp. 1068-1077. http://dx.doi.org/10.1016/j.fuproc.2010.12.033

[20] P. N. Slater, G. H. Richards and J. N. Harb, "Pyrite and Illite Associations in 2 Eastern US Bituminous Coals," Fuel Processing Technology, Vol. 44, No. 1-3, 1995, pp. 55-69. http://dx.doi.org/10.1016/0378-3820(94)00117-C

[21] D. Brooker, "Chemistry of Deposit Formation in a Coal Gasification Syngas Cooler,” Fuel, Vol. 72, No. 5, 1993, pp. 665-670. http://dx.doi.org/10.1016/0016-2361(93)90579-Q

[22] R. W. Bryers, "Fireside Slagging, Fouling, and High-Temperature Corrosion of Heat-Transfer Surface Due to Impurities in Steam-Raising Fuels," Progress in Energy and Combustion Science, Vol. 22, No. 1, 1996, pp. 29-120. http://dx.doi.org/10.1016/0360-1285(95)00012-7

[23] G. Couch, "Understanding Slagging and Fouling in pf Combustion," IEA Coal Research, Report No. IEACR/72, 1994.

[24] J. L. Yu, J. Lucas, V. Strezov and T. Wall, "Swelling and Char Structures from Density Fractions of Pulverized Coal," Energy \& Fuels, Vol. 17, No. 5, 2003, pp. 11601174. http://dx.doi.org/10.1021/ef030022h

[25] H. Wu, T. Wall, G. Liu and G. Bryant, "Ash Liberation from Included Minerals during Combustion of Pulverized Coal: The Relationship with Char Structure and Burnout," Energy and Fuels, Vol. 13, No. 6, 1999, pp. 1197 1202. http://dx.doi.org/10.1021/ef9900810

[26] V. T. Sathyanathan and K. P. Mohammad, "Prediction of Unburnt Carbon in Tangentially Fired Boiler Using Indian Coals," Fuel, Vol. 83, No. 16, 2004, pp. 2217-2227. http://dx.doi.org/10.1016/j.fuel.2004.05.004

[27] J. R. Bunt and F. B. Waanders, "An Understanding of Lump Coal Physical Property Behaviour (Density and Particle Size Effects) Impacting on a Commercial-Scale Sasol-Lurgi FBDB Gasifier," Fuel, Vol. 87, No. 13-14, 2008, pp. 2856-2865.

http://dx.doi.org/10.1016/j.fuel.2008.03.022 
[28] R. P. Gupta, T. F. Wall, I. Kajigaya, S. Miyamae and Y. Tsumita, "Computer-Controlled Scanning Electron Microscopy of Minerals in Coal-Implications for Ash Deposition," Progress in Energy and Combustion Science, Vol. 24, No. 6, 1998, pp. 523-543. http://dx.doi.org/10.1016/S0360-1285(98)00009-4

[29] M. Fajardo, J. Mojica, J. Barraza, G. A. P. Alcazar and J. A. Tabares, "Mineral Identification in Colombian Coals Using Mossbauer Spectroscopy and X-Ray Diffraction," Hyperfine Interactions, Vol. 122, No. 1-2, 1999, pp. 129138. http://dx.doi.org/10.1023/A:1012697723308

[30] K. M. Djamarani and I. M. Clark, "Characterization of Particle Size Based on Fine and Coarse Fractions," Powder Technology, Vol. 93, No. 2, 1997, pp. 101-108. http://dx.doi.org/10.1016/S0032-5910(97)03233-6

[31] G. R. Dyrkacz, C. A. A. Bloomquist, L. Ruscic and E. P. Horwitz, "Variations in Properties of Coal Macerals Elucidated by Density Gradient Separation," ACS Symposium Series, Vol. 252, 1984, pp. 65-77. http://dx.doi.org/10.1021/bk-1984-0252.ch005

[32] G. H. Taylor, M. Teichmüller and C. Davis, "Organic Petrology: A New Handbook Incorporating Some Revised Parts of Stach's Textbook of Coal Petrology," Gebrüder Borntraeger, Berlin, 1998.

[33] B. Nandi, T. Brown and G. Lee, "Inert Coal Macerals in Combustion," Fuel, Vol. 56, No. 2, 1977, pp. 125-130. http://dx.doi.org/10.1016/0016-2361(77)90130-2

[34] I. S. Ruiz and C. R. Ward, "Chapter 4-Coal Combustion, in Applied Coal Petrology," Elsevier, Burlington, 2008, pp. 85-117. http://dx.doi.org/10.1016/B978-0-08-045051-3.00004-X

[35] S. F. Miller and H. H. Schobert, "Effect of Fuel Particle and Droplet Size Distribution on Particle-Size Distribution of Char and Ash during Pilot-Scale Combustion of Pulverized Coal and Coal-Water Slurry Fuels," Energy \& Fuels, Vol. 7, No. 4, 1993, pp. 520-531. http://dx.doi.org/10.1021/ef00040a013

[36] J. N. Harb, "Investigation of Mineral Transformations and Ash Deposition during Staged Combustion," Quarterly
Technical Progress Report, 1 January 1996-31 March 1996. www.osti.gov

[37] C. Sheng, C. D. Sheng, J. Lin, Y. Li and C. Wang, "Transformation Behaviors of Excluded Pyrite during $\mathrm{O}_{2} / \mathrm{CO}_{2}$ Combustion of Pulverized Coal," Asia-Pacific Journal of Chemical Engineering, Vol. 5, No. 2, 2010, pp. 304-309. http://dx.doi.org/10.1002/apj.277

[38] M. G. Thomas, T. D. Padrick, F. V. Stohl, F. V. Stephens and P. Howard, "Decomposition of Pyrite under Coal Liquefaction Conditions: A Kinetic Study," Fuel, Vol. 61, No. 8, 1982, pp. 761-764. http://dx.doi.org/10.1016/0016-2361(82)90253-8

[39] S. Srinivasachar, J. J. Helble and A. A. Boni, "Mineral Behavior during Coal Combustion.1. Pyrite Transformations," Progress in Energy and Combustion Science, Vol. 16, No. 4, 1990, pp. 281-292. http://dx.doi.org/10.1016/0360-1285(90)90037-4

[40] M. Loubser and S. Verryn, "Combining XRF and XRD Analyses and Sample Preparation to Solve Mineralogical Problems," South African Journal of Geology, Vol. 111, No. 2-3, 2008, pp. 229-238. http://dx.doi.org/10.2113/gssajg.111.2-3.229

[41] C. R. Ward and D. French, "Determination of Glass Content and Estimation of Glass Composition in Fly Ash Using Quantitative X-Ray Diffractometry," Fuel, Vol. 85, No. 16, 2006, pp. 2268-2277.

http://dx.doi.org/10.1016/j.fuel.2005.12.026

[42] M. A. Wisdom, et al., "Quantitative XRD Analysis of Coal Combustion By-Products," Abstracts of Papers of the American Chemical Society, Vol. 219, 2000, p. U399.

[43] Y. Hiei and H. Shirai, "Basic Study on Mineral Removal from Coal-The Influence of Mineral Distribution and Size of Pulverized Coal on Characteristics of Mineral Removal," Coal Preparation, Vol. 26, No. 3, 2006, pp. 137 148. http://dx.doi.org/10.1080/07349340600969633

[44] Y. H. Liu, R. Gupta and T. Wall, "Ash Formation from Excluded Minerals including Consideration of MineralMineral Associations," Energy \& Fuels, Vol. 21, No. 2, 2007, pp. 461-467. http://dx.doi.org/10.1021/ef060414z 